AperTO - Archivio Istituzionale Open Access dell'Università di Torino

\title{
Fundamental Aspects of H2S Adsorption on CPO-27-Ni
}

\section{This is the author's manuscript}

Original Citation:

\section{Availability:}

This version is available http://hdl.handle.net/2318/138529

since 2016-10-08T15:42:51Z

Published version:

DOI:10.1021/jp402440u

Terms of use:

Open Access

Anyone can freely access the full text of works made available as "Open Access". Works made available under a Creative Commons license can be used according to the terms and conditions of said license. Use of all other works requires consent of the right holder (author or publisher) if not exempted from copyright protection by the applicable law. 


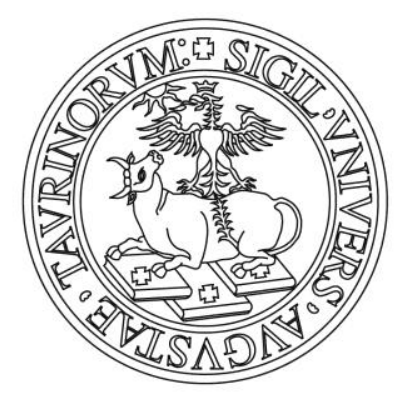

\section{UNIVERSITÀ DEGLI STUDI DI TORINO}

\section{This is an author version of the contribution published on:}

Questa è la versione dell'autore dell'opera:

Sachin Chavan, Frencesca Bonino, Loredana Valenzano, Bartolomeo Civalleri, Carlo

Lamberti, Nadia Acerbi, Jasmina H. Cavka, Matthias Leistner and Silvia Bordiga

"Fundamental aspects of $\mathbf{H}_{2} \mathbf{S}$ adsorption on CPO-27-Ni",

J. Phys. Chem. C 2013, 117, 15615-15622 DOI: 10.1021/jp402440u

The definitive version is available at:

La versione definitiva è disponibile alla URL:

http://pubs.acs.org/doi/abs/10.1021/jp402440u

\section{Published by the ACS}




\title{
Fundamental aspects of $\mathrm{H}_{2} \mathrm{~S}$ adsorption on CPO-27-Ni
}

Sachin Chavan ${ }^{\mathrm{a}, \mathrm{b},}$ Frencesca Bonino $^{\mathrm{a}}$, Loredana Valenzano ${ }^{\mathrm{c}}$, Bartolomeo Civalleri ${ }^{\mathrm{a}}$, Carlo Lamberti $^{\mathrm{a}}$, Nadia Acerbi ${ }^{\mathrm{d}}$, Jasmina H. Cavka ${ }^{\mathrm{e}}$, Matthias Leistner ${ }^{\mathrm{f}}$ and Silvia Bordiga $^{{ }^{\mathrm{a}}}$

${ }^{a}$ Department of Chemistry, NIS Centre of Excellence, and INSTM Reference Center, University of Turin, Via G. Quarello 15 I-10135 Torino, Italy

E-mail:Silvia.Bordiga@ unito.it; Tel: +39-011-6708373

${ }^{b}$ present address: inGAP Centre of Research-Based Innovation, Department of

Chemistry, University of Oslo, Sem Salands vei 26, N-0315 Oslo,Norway

${ }^{c}$ Department of Chemistry, Michigan Technological University, 1400 Townsend Dr, Houghton, MI 49931-1295, USA

'Johnson Matthey Technology Centre, Blount's Court Road, Sonning Common, Reading, RG4 9NH, UK.

${ }^{e}$ SINTEF Materials \& Chemistry, Forskningsveien 1, N-0373 Oslo, Norway

${ }^{f}$ Department Chemical Surface and Reaction Technology Fraunhofer-Institute for Material and Beam Technology IWS Winterbergstrasse 28, 01277 Dresden, Germany

\begin{abstract}
Adsorption of $\mathrm{H}_{2} \mathrm{~S}$ on the $\mathrm{Ni}_{2}(\mathrm{dhtp})\left(\mathrm{H}_{2} \mathrm{O}\right)_{2} \cdot 8 \mathrm{H}_{2} \mathrm{O}$ metal-organic framework (known as CPO27-Ni or MOF-74-Ni) is characterized by in-situ technique (PXRD, FTIR, Raman and Uvvisible spectroscopy) and by first principles periodic boundary conditions calculations. Powder X-ray diffraction results show very high stability of CPO-27-Ni framework in presence of $\mathrm{H}_{2} \mathrm{~S}$. Nevertheless, as evidenced by change in color of the sample from pale yellow to dark green, the adsorption of $\mathrm{H}_{2} \mathrm{~S}$ strongly affects the coordination of Ni sites. FTIR results show the reversible molecular adsorption of $\mathrm{H}_{2} \mathrm{~S}$. Experimental and computed energies of interaction reveal good agreement. Quantitative data considering energetic aspects (calorimetric measurements) are also included. This work highlights the fundamentals of $\mathrm{H}_{2} \mathrm{~S}$ adsorption onto the CPO-27-Ni framework.
\end{abstract}

\section{Introduction}

Over the last decade, metal-organic frameworks have received large interest due to their high porosity with astounding internal surface areas, and framework modularity (both chemical and morphological). ${ }^{1-3}$ These well-defined crystalline networks have suggested several potential applications such as gas separation, gas storage, catalysis, drug delivery, and sensors. Currently, the most feasible practical application of MOFs seems to be gas storage and separation. $^{4-8}$ As gas storage is concerned, MOFs' most appealing properties refer to their huge surface area (with reported values up to $4500 \mathrm{~m}^{2} \mathrm{~g}^{-1}$ for MOF-177 ${ }^{2}$ ) and to their extreme low density. This implies that within such large pore spaces a significant amount of gas can be 
stored. However, high surface area is not a sufficient requirement to guarantee high performance in gas separation or purification, where high affinity towards the selected molecule/s is also necessary. In this regard the capability of the material to selectively operate with respect to a specific guest molecules, has to be tuned by carefully considering operational thermodynamic conditions (pressure, temperature) and gas feed components ${ }^{9,10}$. Organic ligands that constitute most of the MOF structure do not provide strong electrostatic and dispersive forces which are required for the retention of small gas molecules. However, unlike other adsorbents such as activated carbons and polymers, MOFs benefit from a very well-developed structural chemistry which arises from the presence of metallic sites and possible facile functionalization of organic ligands. ${ }^{11-13}$ Therefore, each unit in MOFs (metals or ligands) can be considered as a potential coordination-adsorption site for the target gas. Moreover, gas adsorption via physisorption, chemisorption and/or reactive adsorption on a MOF under control condition have been recently studied. A well-documented example is that of $\mathrm{NH}_{3}$ adsorption on HKUST-1, with and without the presence of $\mathrm{H}_{2} \mathrm{O}^{14}$ or the separation of $\mathrm{O}_{2}$ from $\mathrm{O}_{2} / \mathrm{N}_{2}$ mixture, at liquid nitrogen temperature (reversible) or at room temperature (irreversible). ${ }^{15}$ In both cases it was found that only in specific conditions adsorption was reversible, allowing multi-cycles use of the materials; on the contrary, in other ranges of temperature/gas mixtures, a partial or total collapse of the framework was observed. Framework damage is an easy risk especially in case of interaction with reactive gases like $\mathrm{H}_{2} \mathrm{~S}$ as was observed in previous studies performed on HKUST-1. ${ }^{16-18}$

Recent studies of $\mathrm{H}_{2} \mathrm{~S}$ adsorption on rigid and flexible MILs frameworks were performed. ${ }^{19-21}$ In particular, Mil-53(Al) has shown high performance and reversibility towards $\mathrm{H}_{2} \mathrm{~S}$ adsorption. ${ }^{22}$ Allan et al. observed good adsorption properties towards $\mathrm{H}_{2} \mathrm{~S}$, both in term of stored capacity and framework stability on a MOF with densely exposed metal sites CPO-27-Ni. ${ }^{23}$ Their data indicate that the framework structure is retained throughout the dehydration/gas loading process and only a small loss of deliverable gas capacity over a six month period was observed. In the present study we report a detailed characterization of $\mathrm{H}_{2} \mathrm{~S}$ adducts on CPO-27-Ni described by IR, Raman, UV-Visible spectroscopy, microcalorimetry and PXRD and ab-initio periodic calculations. First, attempts in the evaluation of the reversibility of the adsorption/desorption processes, effects of aging in $\mathrm{H}_{2} \mathrm{~S}$ are reported. 


\section{Experimental and computational methods}

\subsection{Materials and experimental methods}

CPO-27-Ni synthesis: Following the procedure reported into the literature ${ }^{24}$ the $\mathrm{CPO}-27-\mathrm{Ni}$ material was prepared from a nickel(II) acetate and 2,5-dihydroxyterephthalic acid reaction in a THF-water mixture giving an ochre substance $\mathrm{Ni}_{2}(\operatorname{dhtp})\left(\mathrm{H}_{2} \mathrm{O}\right)_{2} \cdot 8 \mathrm{H}_{2} \mathrm{O}$. X-ray powder data showed the high crystallinity of the sample for which a BET surface area of $1200 \mathrm{~m}^{2} \mathrm{~g}^{-1}$ was evaluated (Langmuir surface area of $1315 \mathrm{~m}^{2} \mathrm{~g}^{-1}$ ). The sample was stable to moisture and aging, maintaining its high crystallinity and porosity.

Powder X-ray diffraction: In situ powder X-ray diffraction patterns were collected with a PW3050/60 X'Pert PRO MPD diffractometer (PAN analytical) in Debye-Scherrer geometry. The sample was placed inside $1.0 \mathrm{~mm}$ boron-silicate capillaries, exposed to $60 \mathrm{mbar}_{2} \mathrm{~S}$, and then sealed.

IR spectroscopy: FTIR spectra were collected in transmission mode on self-supporting wafer, and in controlled atmosphere using a home build IR cell. The spectra were recorded at $2 \mathrm{~cm}^{-1}$ resolution on a Bruker IFS 66 FTIR spectrometer equipped with a MCT detector.

Raman spectroscopy Raman spectra were recorded using a Renishaw Raman Microscope spectrometer. An $\mathrm{Ar}^{+}$laser emitting at $514 \mathrm{~nm}$ was used, where the output power was limited to $1 \%(100 \%$ power $=8.2 \mathrm{~mW}$ at the sample $)$. This constraint was necessary in order to avoid sample damage. The photons scattered by the sample were dispersed by a 1800 lines $/ \mathrm{mm}$ grating monochromator and simultaneously collected on a CCD camera; the collection optic was set at $20 \mathrm{X}$ objective. The spectra were obtained by collecting 50 acquisitions (each of 10 seconds) on a self-supporting wafer put in a home-made cell with a suprasil quartz cuvette that allowed measurements in controlled atmosphere.

Uv-Visible spectroscopy: DR-UV-vis-NIR measurements were performed on a Varian Cary 5000 spectrometer equipped with a reflectance sphere on thick self-supported pellets. In all experiments, samples were put inside an ad hoc cell that allowed thermal treatments under high vacuum conditions, dosage of probe molecules, and in situ spectra collection.

Calorimetry: Calorimetric isotherm data were obtained on a Tian-Calvet-type (Setaram), a calorimeter provided with a calibrated gas-volumetric glass manifold. Pressure was measured by means of a Barocell (Edwards) transducer gauge (0-100 mbar). Adsorption-desorption cycles of $\mathrm{H}_{2} \mathrm{~S}$ at CPO-27-Ni were studied at room temperature on $56.4 \mathrm{mg}$ of the CPO-27-Ni powder sample by following different regeneration methods (by outgassing at RT and at 
$473 \mathrm{~K})$. For all the experiments, prior to the adsorption of $\mathrm{H}_{2} \mathrm{~S}, \mathrm{CPO}-27-\mathrm{Ni}$ was activated (outgassed) at $473 \mathrm{~K}$ for 3 hours in order to reveal coordinatively unsaturated $\mathrm{M}^{2+}$ centers.

\subsection{Computational Methods}

Theoretical investigation was carried out using periodic density functional theory (DFT) calculations employing the hybrid B3LYP ${ }^{25-27}$ functional empirically corrected to include a long-range dispersion term, as proposed by Grimme ${ }^{28}$ and modified for crystalline systems. ${ }^{29}$ All calculations were performed with the CRYSTAL09 code. $^{30,31}$

All-electron Gaussian-type basis sets were used for all of the atoms. A TZVP basis set was chosen for Ni (Gaussian basis functions' exponents lower than 0.1 au were removed) while a TZP basis set was employed for the adsorbed molecules (vide infra Table 3 for details).

For the numerical integration of the exchange-correlation term a $(75,974)$ pruned grid, was adopted. ${ }^{31}$ The condition for the SCF convergence was set to 10-8 and 10-10 Hartrees during geometry optimization and vibration frequencies calculation, respectively. The PackMonkhorst/Gilat shrinking factors for the reciprocal space sampling were set to 2, corresponding to $4 \mathrm{k}$-points at which the Hamiltonian matrix was diagonalized. The tolerances for one- and two-electron integrals calculation was set to 777718 (see $\operatorname{Ref}^{31}$ for details).

A full relaxation of the structures (both lattice parameters and atomic positions) was performed by keeping the symmetry of the system; that is, one molecule was placed on each $\mathrm{Ni}$ atom of the unit cell (1:1 molecular loading). All the results refer to $\mathrm{Ni}$ in high-spin electronic configuration within a ferromagnetic unit cell. For geometry optimization, the default convergence criteria were used. ${ }^{31}$ Equilibrium structures were used to compute the binding energies for the adsorbed molecules $\left(\mathrm{H}_{2} \mathrm{O}\right.$ and $\left.\mathrm{H}_{2} \mathrm{~S}\right)$ :

$$
\Delta \mathrm{E}=\mathrm{E}_{\mathrm{MOF} / \mathrm{X}}-\mathrm{E}_{\mathrm{MOF}}-\mathrm{nE} \mathrm{E}_{\mathrm{X}}
$$

where $n=6$ and $X$ indicates the molecule (i.e. $X=\mathrm{H}_{2} \mathrm{~S}, \mathrm{H}_{2} \mathrm{O}$ ). Basis set superposition error (BSSE) was taken into account by using the counterpoise correction (CP) method.

The enthalpy of interaction was computed as:

$$
\Delta \mathrm{H}(\mathrm{T})=\Delta \mathrm{E}^{\mathrm{CP}}+\Delta \mathrm{ZPE}+\Delta \mathrm{H}_{\mathrm{T}}
$$


Where, $\triangle \mathrm{ZPE}$ and $\Delta \mathrm{H}_{\mathrm{T}}$ are the contribution from the zero-point energy and the thermal correction to enthalpy a given temperature, $\mathrm{T}$, respectively. The corresponding value of $\mathrm{T}$ was taken to be $\mathrm{T}=298 \mathrm{~K}$.

\section{Results and discussion}

\subsection{Vibrational spectroscopy: FTIR and Raman}

Vibrational features of CPO-27-Ni have been extensively described previously. ${ }^{11,32-34}$ For sake of clarity Figure 1 reports only the ranges where major changes are occurring upon $\mathrm{H}_{2} \mathrm{~S}$ adsorption (60 mbar equilibrium pressure). The high frequency range of the IR spectrum is reported where stretching modes of $\mathrm{H}_{2} \mathrm{~S}$ occur (Parts a and b). On the other hand, the low frequency range for the active Raman modes is reported (Part c) where some of the framework modes are perturbed and some direct evidence of $\mathrm{H}_{2} \mathrm{~S}$ coordination could be singled out. The IR spectrum of CPO-27-Ni in contact with 60 mbar of $\mathrm{H}_{2} \mathrm{~S}$ is reported as a red curve in Figure 1, while the effects of progressive outgassing at room temperature are reported as grey curves. The last spectrum, obtained after $3 \mathrm{~h}$ of outgassing does not show clear evidence of significant amount of irreversibly adsorbed $\mathrm{H}_{2} \mathrm{~S}$.

Molecular $\mathrm{H}_{2} \mathrm{~S}$ is characterised by three IR active vibrational mode at 2626, 2614 and $1182 \mathrm{~cm}^{-1}$ corresponding to the asymmetric, symmetric stretching, and bending vibrational modes. ${ }^{35}$ The presence of $\mathrm{H}_{2} \mathrm{~S}$ adsorbed on CPO-27-Ni is indicated in the IR spectrum by the presence of a doublet at 2565 and $2524 \mathrm{~cm}^{-1}$. These asymmetric and symmetric (S-H) stretching vibrations of the adsorbed $\mathrm{H}_{2} \mathrm{~S}$ are red shifted by 61 and $90 \mathrm{~cm}^{-1}$ respectively with respect to the gas phase values. Due to the fact that upon $\mathrm{H}_{2} \mathrm{~S}$ adsorption most of the framework bands are slightly shifted, any attempt to magnify specific features of the adsorbed $\mathrm{H}_{2} \mathrm{~S}$ performing spectra subtraction, was not satisfactory.

In comparison, IR spectrum for $\mathrm{H}_{2} \mathrm{~S}$ adsorbed on MIL-47(V) shows a broad absorption band centred at $2585 \mathrm{~cm}^{-1}$ with shoulder at $2560 \mathrm{~cm}^{-1} .{ }^{19}$ These dramatic shifts in the (S-H) stretch observed on CPO-27-Ni and the change from yellow to dark green of the activated sample upon $\mathrm{H}_{2} \mathrm{~S}$ adsorption indicate the involvement of $\mathrm{Ni}^{2+}$ sites into the adsorption mechanism. The mentioned change in colour is further investigated by Uv-Visible spectroscopy as described in the next section. 


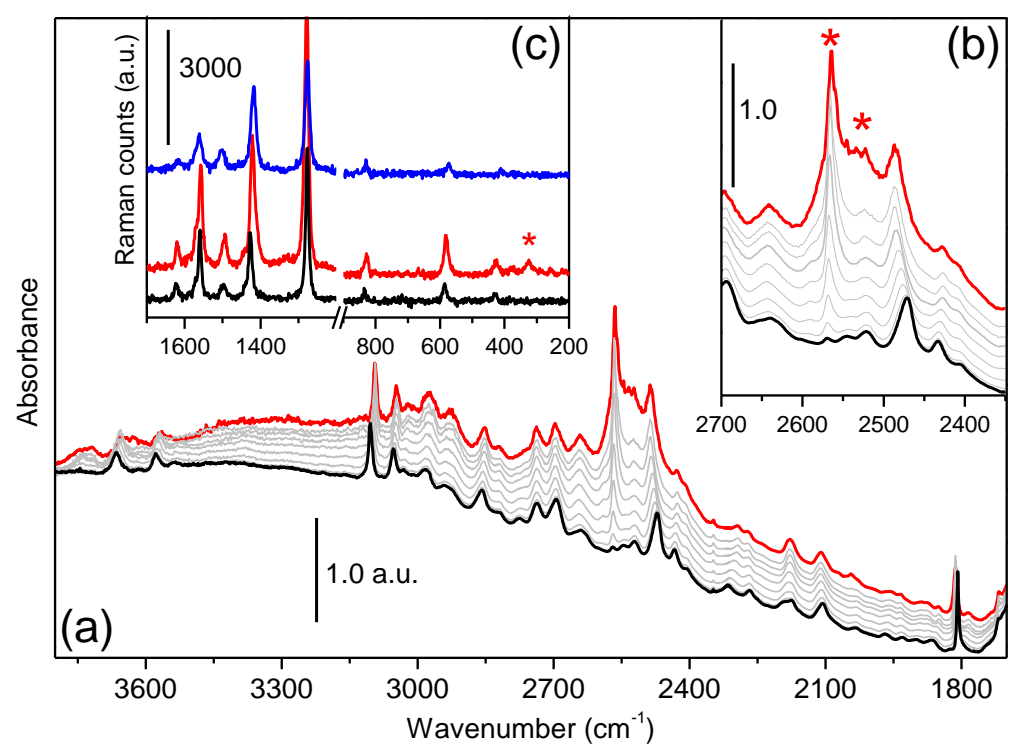

Figure 1: FTIR (a and b) and Raman spectra (c) of CPO-27-Ni: As prepared (blue curve); activated at $473 \mathrm{~K}$ for $3 \mathrm{~h}$ (black), in contact with $\mathrm{H}_{2} \mathrm{~S}$ (red curve at $60 \mathrm{mbar}$ ); and following desorption of $\mathrm{H}_{2} \mathrm{~S}$ (grey curves) at ambient temperature.

Figure 1c compares the Raman spectrum of the activated CPO-27-Ni (black curve) and when in interaction with $\mathrm{H}_{2} \mathrm{~S}$ (red curve). The blue curve represents the hydrated sample, which is reported for further comparison. The dehydrated form of CPO-27-Ni shows bands at 1625,1561 and $586 \mathrm{~cm}^{-1}$. They are due to benzene ring vibrations; the former two refer to stretching modes, the latter to a ring deformation. ${ }^{32}$ Features at 1495 and $1428 \mathrm{~cm}^{-1}$ are assigned to $v\left(\mathrm{COO}^{-}\right)_{\text {asym }}$ and $v\left(\mathrm{COO}^{-}\right)_{\text {sym }}$. The intense band at $1277 \mathrm{~cm}^{-1}$ is attributed to $v(\mathrm{CO})$ vibration due to the deprotonated species derived from the hydroxyl group. The minor feature at $835 \mathrm{~cm}^{-1}$ is ascribed to ring $\mathrm{C}-\mathrm{H}$ bending modes. At lower frequency, the band at $430 \mathrm{~cm}^{-1}$ is attributed to the $v\left(\mathrm{Ni}-\mathrm{O}_{\text {Ligand }}\right)$ mode. ${ }^{36,37}$ Upon $\mathrm{H}_{2} \mathrm{~S}$ coordination, some relevant changes occur in the framework vibrational region in both the frequency and the relative intensities of the Raman bands. The spectra are reported only in the low frequency region due to the very low intensity of $v(\mathrm{HS})$ modes. As far as the frequency shifts are concerned, most of the components are sensibly red-shifted (the bands at 1625, 1561, 1427, 1278, 833, 586 and 430 $\mathrm{cm}^{-1}$ shift down to $1618,1558,1415,1273,827,570$ and $410 \mathrm{~cm}^{-1}$, respectively). Exception is made for the band around $1500 \mathrm{~cm}^{-1}$ that remains almost un-shifted. The additional component, observed at $327 \mathrm{~cm}^{-1}$ and absent in both activated and hydrated CPO-27-Ni, could be associated to the vibration of the Ni-S bond of the coordinated $\mathrm{H}_{2} \mathrm{~S}$. Due to its very low Raman intensity, no evidence is recorded of the $v(\mathrm{HS})$ mode. For this reason, the hypothesis 
of $\mathrm{H}_{2} \mathrm{~S}$ decomposition under the laser beam and the consequence formation of $\mathrm{S}$ deposition cannot be totally discarded.

\subsection{Uv-Visible-NIR spectroscopy}

Despite from the observation derived from IR and Raman spectra one might expect the adsorption of $\mathrm{H}_{2} \mathrm{~S}$ to show features similar to that of water, the macroscopic change in colour of the sample (from yellow to dark green) indicates that $\mathrm{H}_{2} \mathrm{~S}$ has a much stronger effect on the electronic structure of $\mathrm{Ni}$ sites than $\mathrm{H}_{2} \mathrm{O}$. Figure 2 compares the electronic spectra of CPO-27$\mathrm{Ni}$ as prepared (blue curve), activated (black curve), and upon $\mathrm{H}_{2} \mathrm{~S}$ adsorption (red curve). The spectrum of the hydrated sample (in which water is coordinated to the $\mathrm{Ni}$ site) is characterized by the presence of three main features: a band at $9300 \mathrm{~cm}^{-1}$, a doublet at 13605 and $15080 \mathrm{~cm}^{-1}$ and an intense absorption with an edge at about $21500 \mathrm{~cm}^{-1}$. This latter component is associated with the lowest $\pi-\pi^{*}$ energy transition due to the organic linker. Three spin allowed d-d excitations are expected for a $\mathrm{Ni}^{2+}$ ion in $O_{\mathrm{h}}$ symmetry. However, due to the low lying charge transfer region of the MOF-linker, the optical spectrum clearly shows only the two dd-excitations $\left({ }^{3} \mathrm{~A}_{2 \mathrm{~g}}\left({ }^{3} \mathrm{~F}\right) \rightarrow{ }^{3} \mathrm{~T}_{2 \mathrm{~g}}\left({ }^{3} \mathrm{~F}\right)\right.$ and $\left.{ }^{3} \mathrm{~A}_{2 \mathrm{~g}}\left({ }^{3} \mathrm{~F}\right) \rightarrow{ }^{3} \mathrm{~T}_{1 \mathrm{~g}}\left({ }^{3} \mathrm{~F}\right)\right)$ at low energy ${ }^{32}$ while the expected d-d at high energy $\left({ }^{3} \mathrm{~A}_{2 \mathrm{~g}}\left({ }^{3} \mathrm{~F}\right) \rightarrow{ }^{3} \mathrm{~T}_{1 \mathrm{~g}}\left({ }^{3} \mathrm{P}\right)\right.$ appears just as a shoulder. The position of this $\mathrm{d}$ - $\mathrm{d}$ transition has been reported only recently to be at $24800 \mathrm{~cm}^{-1}$ by Gallo et al. ${ }^{38}$ using resonant inelastic X-ray scattering (RIXS) ${ }^{39-41}$ The technique, being element selective at the Ni K-edge, does not detect the $\pi \rightarrow \pi^{*}$ transition of the ligand (as UV-Vis does) and so the $\mathrm{Ni}^{2+} \mathrm{d}-\mathrm{d}$ transitions emerges clearely. ${ }^{42}$

The thermal treatment in vacuo at $473 \mathrm{~K}$ produces a blue shift for all the components and the appearance of a new band at $5730 \mathrm{~cm}^{-1}$. Remaining components are observed at 10160, 14200 and 25000 (the latter clearly observed in RIXS experiments only), see Table 1. This profile has been interpreted on the basis of a five-coordinated $\mathrm{Ni}^{2+}$ species in a squaredpyramidal geometry $\left(C_{4 \mathrm{~V}}\right.$ space group: the assignment of the electronic transitions is as it follows: $\quad{ }^{3} \mathrm{~B}_{1}\left({ }^{3} \mathrm{~F}\right) \rightarrow{ }^{3} \mathrm{E}(1)\left({ }^{3} \mathrm{~F}\right), \quad{ }^{3} \mathrm{~B}_{1}\left({ }^{3} \mathrm{~F}\right) \rightarrow{ }^{3} \mathrm{~A}_{2}\left({ }^{3} \mathrm{~F}\right), \quad{ }^{3} \mathrm{~B}_{1}\left({ }^{3} \mathrm{~F}\right) \rightarrow{ }^{3} \mathrm{~B}_{2}\left({ }^{3} \mathrm{~F}\right), \quad{ }^{3} \mathrm{~B}_{1}\left({ }^{3} \mathrm{~F}\right) \rightarrow{ }^{3} \mathrm{E}(2)\left({ }^{3} \mathrm{P}\right)$, ${ }^{3} \mathrm{~B}_{1}\left({ }^{3} \mathrm{~F}\right) \rightarrow{ }^{3} \mathrm{~A}_{2}\left({ }^{3} \mathrm{P}\right) .{ }^{32,}{ }^{43} \mathrm{H}_{2} \mathrm{~S}$ adsorption (60 mbar equilibrium pressure at $\mathrm{RT}$, red curve) on activated CPO-27-Ni causes the erosion of the component at $5730 \mathrm{~cm}^{-1}$, while the other $d-d$ transitions now appear at 9430, 15400and $25500 \mathrm{~cm}^{-1}$ respectively(the latter visible in RIXS experiments, only); finally, the component due to the organic linker (lowest $\pi-\pi^{*}$ ) is slightly red shifted at about $19500 \mathrm{~cm}^{-1}$. The fact that the same number of major components are observed in the spectrum obtained in presence of coordinated water (blue curve) implies that the $\mathrm{Ni}^{2+}$ sites are in octahedral symmetry also when coordinating with $\mathrm{H}_{2} \mathrm{~S}$. Furthermore, the 
consistent change in color, even more dramatic than that observed for $\mathrm{NO}^{32}$ is reflected by the significantly different positions of the bands. The data are summarized in Table 1.

Table 1. Maximum of the $\mathrm{Ni}^{2+} \mathrm{d}-\mathrm{d}$ bands observed by UV-Vis spectroscopy, in $\mathrm{cm}^{-1}$ and corresponding assignment according to literature, ${ }^{32,43}$ supposing an $O_{\mathrm{h}^{-}}$or a $C_{4 \mathrm{v}}$-like local symmetry for $\mathrm{Ni}^{2+}$ in presence and absence of adsorbents $\left(\mathrm{H}_{2} \mathrm{O}\right.$ or $\left.\mathrm{H}_{2} \mathrm{~S}\right)$, respectively.

\begin{tabular}{|c|c|c|}
\hline System & Band position $\left(\mathrm{cm}^{-1}\right)$ & assignment \\
\hline \multirow{3}{*}{$\begin{array}{l}\text { CPO-27-Ni } \\
\text { hydrated }\end{array}$} & $25000^{\mathrm{a}}$ & ${ }^{3} \mathrm{~A}_{2 \mathrm{~g}}\left({ }^{3} \mathrm{~F}\right) \rightarrow{ }^{3} \mathrm{~T}_{1 \mathrm{~g}}\left({ }^{3} \mathrm{P}\right)$ \\
\hline & $15082-13605$ & ${ }^{3} \mathrm{~A}_{2 \mathrm{~g}}\left({ }^{3} \mathrm{~F}\right) \rightarrow{ }^{3} \mathrm{~T}_{1 \mathrm{~g}}\left({ }^{3} \mathrm{~F}\right)$ \\
\hline & 9300 & ${ }^{3} \mathrm{~A}_{2 \mathrm{~g}}\left({ }^{3} \mathrm{~F}\right) \rightarrow{ }^{3} \mathrm{~T}_{2 \mathrm{~g}}\left({ }^{3} \mathrm{~F}\right)$ \\
\hline \multirow{4}{*}{$\begin{array}{l}\text { CPO-27-Ni } \\
\text { de-hydrated }\end{array}$} & $25000^{\mathrm{a}}$ & ${ }^{3} \mathrm{~B}_{1}\left({ }^{3} \mathrm{~F}\right) \rightarrow{ }^{3} \mathrm{E}(1)\left({ }^{3} \mathrm{~F}\right)$ \\
\hline & 14200 & ${ }^{3} \mathrm{~B}_{1}\left({ }^{3} \mathrm{~F}\right) \rightarrow{ }^{3} \mathrm{~A}_{2}\left({ }^{3} \mathrm{~F}\right)$ \\
\hline & 10160 & ${ }^{3} \mathrm{~B}_{1}\left({ }^{3} \mathrm{~F}\right) \rightarrow{ }^{3} \mathrm{~B}_{2}\left({ }^{3} \mathrm{~F}\right)$ \\
\hline & 5730 & ${ }^{3} \mathrm{~B}_{1}\left({ }^{3} \mathrm{~F}\right) \rightarrow{ }^{3} \mathrm{~A}_{2}\left({ }^{3} \mathrm{P}\right)$ \\
\hline \multirow{3}{*}{$\begin{array}{l}\mathrm{CPO}-27-\mathrm{Ni}+ \\
\mathrm{H}_{2} \mathrm{~S}\end{array}$} & $25500^{b}$ & ${ }^{3} \mathrm{~A}_{2 \mathrm{~g}}\left({ }^{3} \mathrm{~F}\right) \rightarrow{ }^{3} \mathrm{~T}_{1 \mathrm{~g}}\left({ }^{3} \mathrm{P}\right)$ \\
\hline & 15400 & ${ }^{3} \mathrm{~A}_{2 \mathrm{~g}}\left({ }^{3} \mathrm{~F}\right) \rightarrow{ }^{3} \mathrm{~T}_{1 \mathrm{~g}}\left({ }^{3} \mathrm{~F}\right)$ \\
\hline & 9430 & ${ }^{3} \mathrm{~A}_{2 \mathrm{~g}}\left({ }^{3} \mathrm{~F}\right) \rightarrow{ }^{3} \mathrm{~T}_{2 \mathrm{~g}}\left({ }^{3} \mathrm{~F}\right)$ \\
\hline
\end{tabular}

${ }^{\mathrm{a}}$ The exact band position has been observed by RIXS and reported in Ref. ${ }^{38}$, for the hydrated sample. RIXS data of the de-hydrated sample and after interaction with $\mathrm{H}_{2} \mathrm{~S}$ have been kindly supplied by E. Gallo and P. Glatzel (ESRF), prior publication.

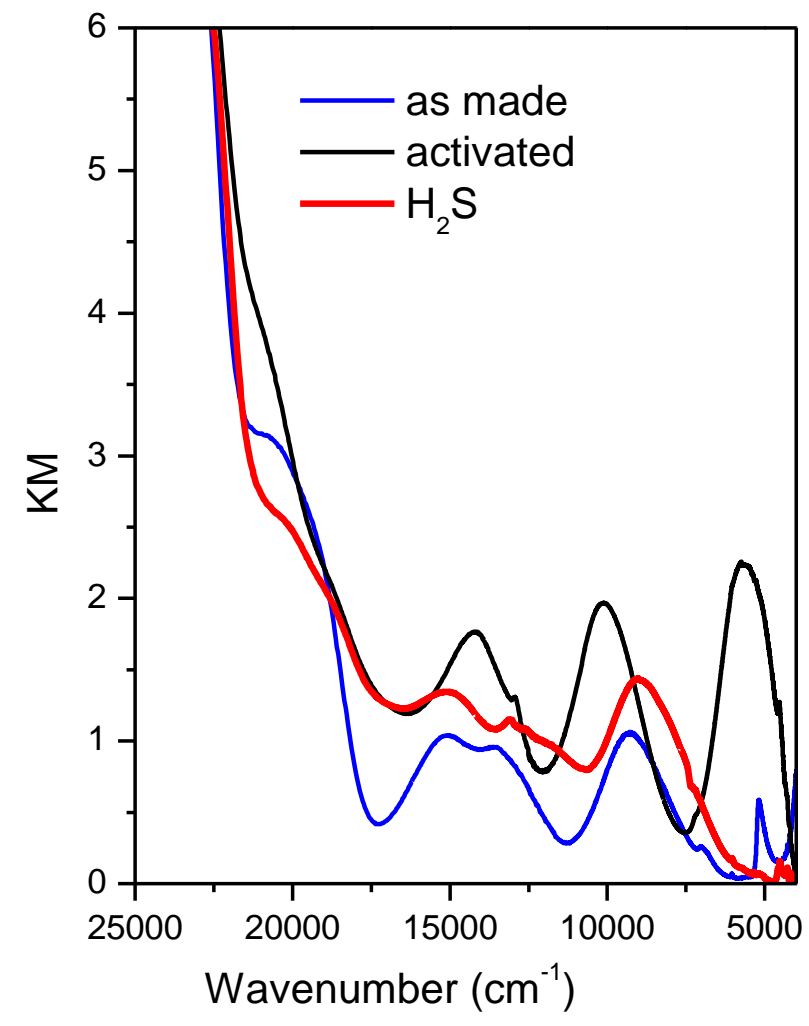

Figure 2: DIR-Uv-Visi-NIR spectra of CPO-27-Ni: As prepared (blue curve), activated (black curve) and with $\mathrm{H}_{2} \mathrm{~S}$ adsorbed (red curve, 60 Torr equilibrium pressure). 


\subsection{Microcalorimetry}

Enthalpy of $\mathrm{H}_{2} \mathrm{~S}$ adsorption at exposed nickel sites and the adsorption capacity of the CPO27-Ni were evaluated by measuring calorimetric adsorption isotherms. Volumetric isotherms as a function of equilibrium pressure are illustrated in Figure 3. The primary adsorption isotherm (filled red square) was measured on a pristine CPO-27-Ni sample activated under vacuum at $473 \mathrm{~K}$. This sample was regenerated following the $\mathrm{H}_{2} \mathrm{~S}$ desorption at room temperature $(303 \mathrm{~K})$ and secondary adsorption isotherm was measured (empty red square). Difference between primary and secondary isotherms clearly indicates that, some amount of $\mathrm{H}_{2} \mathrm{~S}$ is not removed by outgassing the sample at room temperature. With the aim of providing evidence about the potential of the material in recyclable cycles, the same CPO-27-Ni sample was regenerated by desorbing $\mathrm{H}_{2} \mathrm{~S}$ at $473 \mathrm{~K}$ for $12 \mathrm{~h}$ after secondary isotherm. Re-adsorption of $\mathrm{H}_{2} \mathrm{~S}$ on this regenerated sample (filled black square) shows more uptake than that observed for the freshly activated one (filled red square). A subsequent $3 \mathrm{~h} \mathrm{H}_{2} \mathrm{~S}$ desorption at $473 \mathrm{~K}$ was performed before to run another $\mathrm{H}_{2} \mathrm{~S}$ adsorption isotherm (black empty square); no significant changes could be appreciated with respect to the previous scenario.

All the reported isotherms show type I behavior in which the saturation is reached at low pressure (< 1 mbar); i.e., the suitable pressure range for natural gas purification, which contains $\mathrm{H}_{2} \mathrm{~S}$ in ppm level. Considering a 1:1 stoichiometry between adsorbed $\mathrm{H}_{2} \mathrm{~S}$ and nickel site, and taking into account all the nickel atoms available for the adsorption, the adsorbed moles of $\mathrm{H}_{2} \mathrm{~S}\left(\mathrm{n}_{\mathrm{a}}\right)$ are normalized to the moles of the activated CPO-27-Ni (empirical formula of CPO-27-Ni: $\mathrm{C}_{4} \mathrm{HO}_{3} \mathrm{Ni}, 155.7401 \mathrm{~g} \cdot \mathrm{mol}^{-1}$ ). The weight $\%$ is calculated over the sum of the mass of $\mathrm{H}_{2} \mathrm{~S}$ adsorbed and mass of the activated CPO-27-Ni. The maximum $17 \mathrm{wt} \%$ uptake corresponds to the formation of a 1:1 complex. For freshly activated sample (filled red squares) and samples regenerated at $473 \mathrm{~K}$, (filled and empty black squares) an uptake of $\sim 0.68$ moles of $\mathrm{H}_{2} \mathrm{~S}$ per mole of $\mathrm{C}_{4} \mathrm{HO}_{3} \mathrm{Ni}$ is observed; this corresponds to $13 \mathrm{wt} \%$ of $\mathrm{H}_{2} \mathrm{~S}$. Note that this value is in complete agreement with the one obtained in previous studies performed on CPO-27-Ni in presence of other probes ( $\mathrm{NO}$ and $\mathrm{CO}^{32,34}$ ). Independently to the strength of the interaction, the 1:1 ratio was never observed for this material. This aspect can be linked to the fact that not all the $\mathrm{Ni}^{2+}$ sites are available for adsorption. In fact, the presence of a large amount of packed sample inside the calorimenter cell will limit the complete desorption of the solvent. Note that such an effect does not occur in IR experiments, where the spectra are acquired by employing very thin sample pellets. 


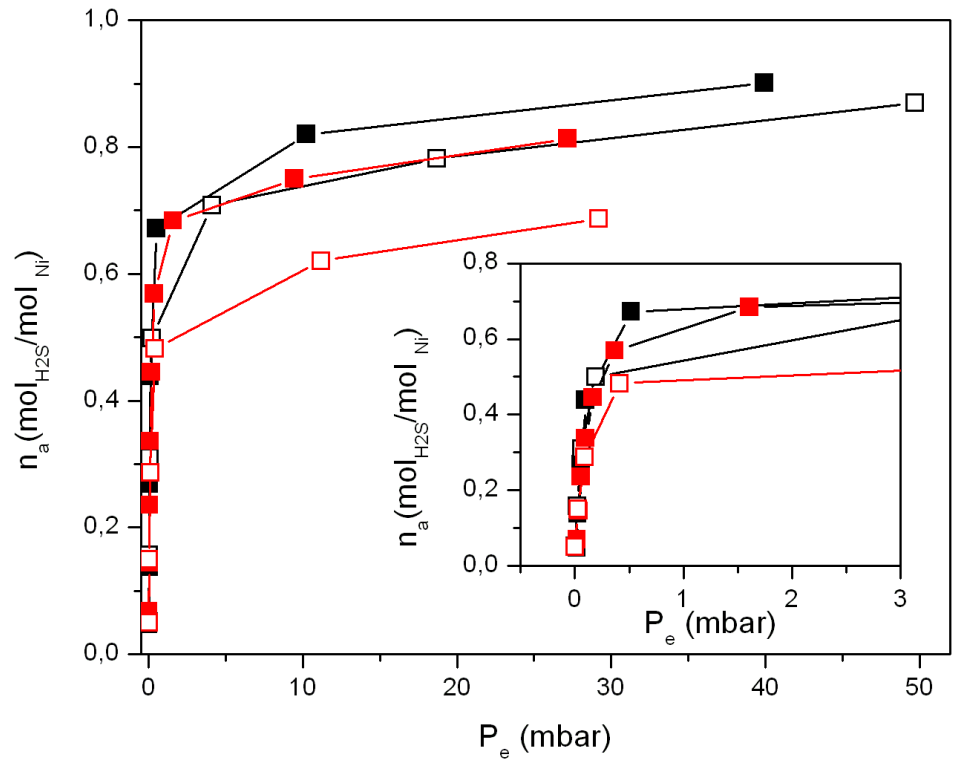

Figure 3: Plot of the volumetric isotherms obtained for $\mathrm{H}_{2} \mathrm{~S}$ adsorption on the CPO-27-Ni activated at $473 \mathrm{~K}$, as the function of the equilibrium pressure $\mathrm{P}_{\mathrm{e}}(\mathrm{m}$ : adsorption isotherm on freshly activated; $\square$ : adsorption isotherm on sample regenerated under vacuum at $303 \mathrm{~K}$, adsorption isotherm on sample regenerated at $473 \mathrm{~K}$ for $12 \mathrm{~h}$, $\square$ : adsorption isotherm on sample regenerated at $473 \mathrm{~K}$ for $3 \mathrm{~h})$. The adsorbed moles of $\mathrm{H}_{2} \mathrm{~S}\left(\mathrm{n}_{\mathrm{a}}\right)$ are normalized to the moles of $\mathrm{Ni}$ atoms present in the MOF sample, supposing all the $\mathrm{Ni}$ atoms available to the interaction with $\mathrm{H}_{2} \mathrm{~S}$. The inset shows the zoom in the $\mathrm{P}_{\mathrm{e}}=0-3$ mbar range.

Figure 4 illustrates the dependence of the differential molar adsorption heat $\mathrm{q}_{\text {diff }}$ as a function of $\mathrm{H}_{2} \mathrm{~S}$ coverage. Except from the isotherm obtained after prolonged re-activation (12 $\mathrm{h}$ in dynamic vacuum at $473 \mathrm{~K}$, filled black squares), which is significantly higher $\left(72 \mathrm{~kJ} \mathrm{~mol}^{-}\right.$ ${ }^{1}$ ) than the initial $q_{\text {diff }}\left(56-58 \mathrm{~kJ} \mathrm{~mole}^{-1}\right)$. This value remains almost constant up to the loading of $\sim 0.7$ mole of $\mathrm{H}_{2} \mathrm{~S}$ per mole of CPO-27-Ni in case of freshly activated (filled red squares) and samples re-generated at $473 \mathrm{~K}$ (full and empty black squares). In case of sample regenerated by outgassing at room temperature, the heat drop is observed at 0.5 moles of $\mathrm{H}_{2} \mathrm{~S}$ per mole of CPO-27-Ni. The decreases in heat of adsorption observed in all cases show similar behavior with drops of about $\sim 30 \mathrm{~kJ} \mathrm{~mol}^{-1}$ (typical of weak physisorption with no specific interaction between the host/guest species).

The fact that the initial heat of adsorption obtained for the sample regenerated at $473 \mathrm{~K}$ for $12 \mathrm{~h}$ (figure 4 filled black squares) is significantly higher than in all the other cases and, knowing that all the Ni sites in $\mathrm{CPO}-27-\mathrm{Ni}$ are equivalent, suggests that this treatment causes some damage to the framework with the consequent formation of defects. We think that, this small fraction $\left(0.1 \mathrm{~mol}\right.$ of $\mathrm{H}_{2} \mathrm{~S} / \mathrm{mol}$ of CPO-27-Ni) of $\mathrm{H}_{2} \mathrm{~S}$ is not reversible even after outgassing at $473 \mathrm{~K}$ for $3 \mathrm{~h}$ (empty black squares). 
Compared to other MOFs so far investigated for $\mathrm{H}_{2} \mathrm{~S}$ adsorption, $\mathrm{CPO}-27-\mathrm{Ni}$ has shown the highest uptake and high enthalpy of adsorption while maintaining its structure and porosity. In the case of HKUST-1, the interaction with $\mathrm{H}_{2} \mathrm{~S}$ is so strong to be able to cause framework decomposition ${ }^{17}$; on the other hand, many cluster- based MOFs show very weak interaction. ${ }^{19,20}$

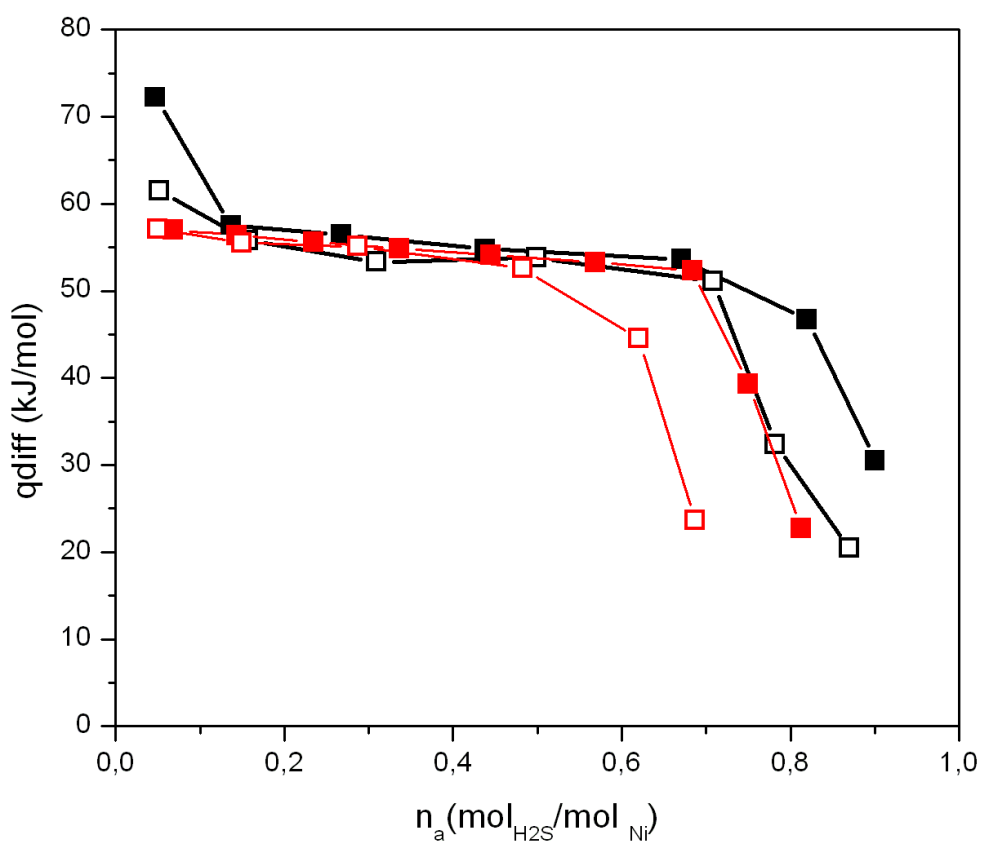

Figure 4: Dependence of the differential molar adsorption heat $q$ diff as a function of $\mathrm{H}_{2} \mathrm{~S}$ coverage on CPO-27-Ni activated at 473K ( $\square$ : adsorption isotherm on freshly activated; $\square$ : adsorption isotherm on sample regenerated under vacuum at $303 \mathrm{~K}$, $\mathbf{m}$ : adsorption isotherm on sample regenerated at $473 \mathrm{~K}$ for $12 \mathrm{~h}, \square$ : adsorption isotherm on sample regenerated at $473 \mathrm{~K}$ for $3 \mathrm{~h}$ ). The adsorbed moles of $\mathrm{H}_{2} \mathrm{~S}_{\mathrm{a}}$ are normalized to the moles of $\mathrm{Ni}$ atoms present in the MOF sample, supposing all the $\mathrm{Ni}$ atoms available to the interaction with $\mathrm{H}_{2} \mathrm{~S}$.

\subsection{Periodic DFT calculations}

The main geometrical and energetic results obtained by periodic calculations at the B3LYPD*/TZVP level of theory with the CRYSTAL09 code $^{31}$ are summarized in Table 2. The optimized structures are shown in Figure 5, as viewed along the [001] direction. All the results refer to $\mathrm{CPO}-27-\mathrm{Ni}$ with nickel atoms in high-spin electronic configuration within a ferromagnetic unit cell and a molecular loading of 1:1 (i.e., one molecule per metal atom) with respect to experimental data of Dietzel et al. ${ }^{24}$ As expected, upon hydration or upon interaction with hydrogen sulfide, the volume of the unit cell increases in agreement with experimental evidence. For CPO-27-Ni in interaction with $\mathrm{H}_{2} \mathrm{~S}$, structural features are in good agreement with the recently reported synchrotron X-ray data at room temperature ${ }^{23}$, with values for lattice parameters and volume lying within $1 \%$ and $2.5 \%$, respectively. For the 
three structures, the average of the $\mathrm{Ni}-\mathrm{O}$ bond distance in the framework and the $\mathrm{Ni}-\mathrm{Ni}$ distances are also in good agreement with experimental data from different techniques ${ }^{24,32}$, despite a slight overestimation.

Table 2. Summary of the main geometrical and energetic features obtained by periodic calculations at the B3LYP-D*/TZVP level of theory. For comparison also the experimental values for $-\Delta H_{a d s}^{e x p}$ are reported.

\begin{tabular}{|c|c|c|c|c|}
\hline & Dehydrated & $+\mathrm{H}_{2} \mathrm{O}$ & $+\mathrm{H}_{2} \mathrm{~S}$ & $\begin{array}{l}\text { Exp }+\mathrm{H}_{2} \mathrm{~S} \\
\text { value from } \\
23\end{array}$ \\
\hline$a=b(\AA)$ & 25.894 & 25.897 & 25.908 & 25.745 \\
\hline$c(\AA)$ & 6.843 & 6.891 & 6.877 & 6.8057 \\
\hline$V\left(\AA^{3}\right)$ & 3973.3 & 4002.2 & 3997.5 & 3906.6 \\
\hline$<R_{0}>(\AA)$ & 2.029 & 2.060 & 2.054 & \\
\hline $\mathrm{R}_{\mathrm{Ni1}}(\AA)$ & 2.935 & 3.013 & 3.002 & \\
\hline $\mathrm{R}_{\mathrm{Ni2} 2}(\AA)$ & 4.921 & 4.990 & 4.977 & \\
\hline $\mathrm{R}_{\text {ads }}(\AA ̊)$ & - & 2.156 & 2.633 & 2.590 \\
\hline$\Delta \mathrm{d}_{\mathrm{AB}} / \Delta \mathrm{d}_{\mathrm{BC}}(\AA)^{\mathrm{a}}$ & - & $\begin{array}{l}+0.005 /+ \\
0.006\end{array}$ & $<+0.001$ & \\
\hline$\theta_{\text {Ni-A-B }}\left({ }^{\circ}\right)$ & - & $99.6 / 111.0$ & $91.5 / 93.7$ & \\
\hline$-\Delta \mathrm{E}^{\mathrm{c}}(\mathrm{BSSE})\left(\mathrm{kJ} \mathrm{mol}{ }^{-1}\right)^{\mathrm{b}}$ & - & $75.5(11.4)$ & $\begin{array}{l}-55.9 \\
(6.5)\end{array}$ & \\
\hline$\triangle \mathrm{ZPE}\left(\mathrm{kJ} \mathrm{mol} \mathrm{l}^{-1}\right)$ & - & 9.7 & 9.4 & \\
\hline$\Delta \mathrm{H}_{\mathrm{T}}(298 \mathrm{~K})\left(\mathrm{kJ} \mathrm{mol}^{-1}\right)$ & - & -2.2 & -1.5 & \\
\hline$-\Delta \mathrm{H}^{0}(298 \mathrm{~K})\left(\mathrm{kJ} \mathrm{mol}^{-1}\right)$ & - & 68.0 & 47.9 & \\
\hline$-\Delta H_{a d s}^{\operatorname{expt}}\left(\mathrm{kJ} \mathrm{mol}{ }^{-1}\right)^{\mathrm{c}}$ & & $>100$ & $57 \pm 1$ & \\
\hline
\end{tabular}

${ }^{\mathrm{a}}$ Intra-molecular distances of the adsorbed $\mathrm{Ni}^{2+} \ldots \mathrm{AB}(\mathrm{C})$ molecule: $\mathrm{AB}(\mathrm{C})=\mathrm{OH}_{2} ; \mathrm{H}_{2} \mathrm{~S}$ For the unperturbed molecules B3-LYP-D*/TZVP distances are: $\mathrm{d}_{\mathrm{AB}}=\mathrm{d}_{\mathrm{BC}}=0.963\left(\mathrm{OH}_{2}\right) ; \mathrm{d}_{\mathrm{AB}}=\mathrm{d}_{\mathrm{BC}}=$ $1.345\left(\mathrm{SH}_{2}\right)$

${ }^{\mathrm{b}}$ Lateral interaction between $\mathrm{H}_{2} \mathrm{O}$ (or $\mathrm{H}_{2} \mathrm{~S}$ ) adjacent molecules is about $-2.0 \mathrm{~kJ} / \mathrm{mol}(\mathrm{Ni}$ ) on average, thus indicating a somewhat weak attractive interaction

c $-\Delta H_{a d s}^{e x p}$ values are obtained by microcalorimetry. 

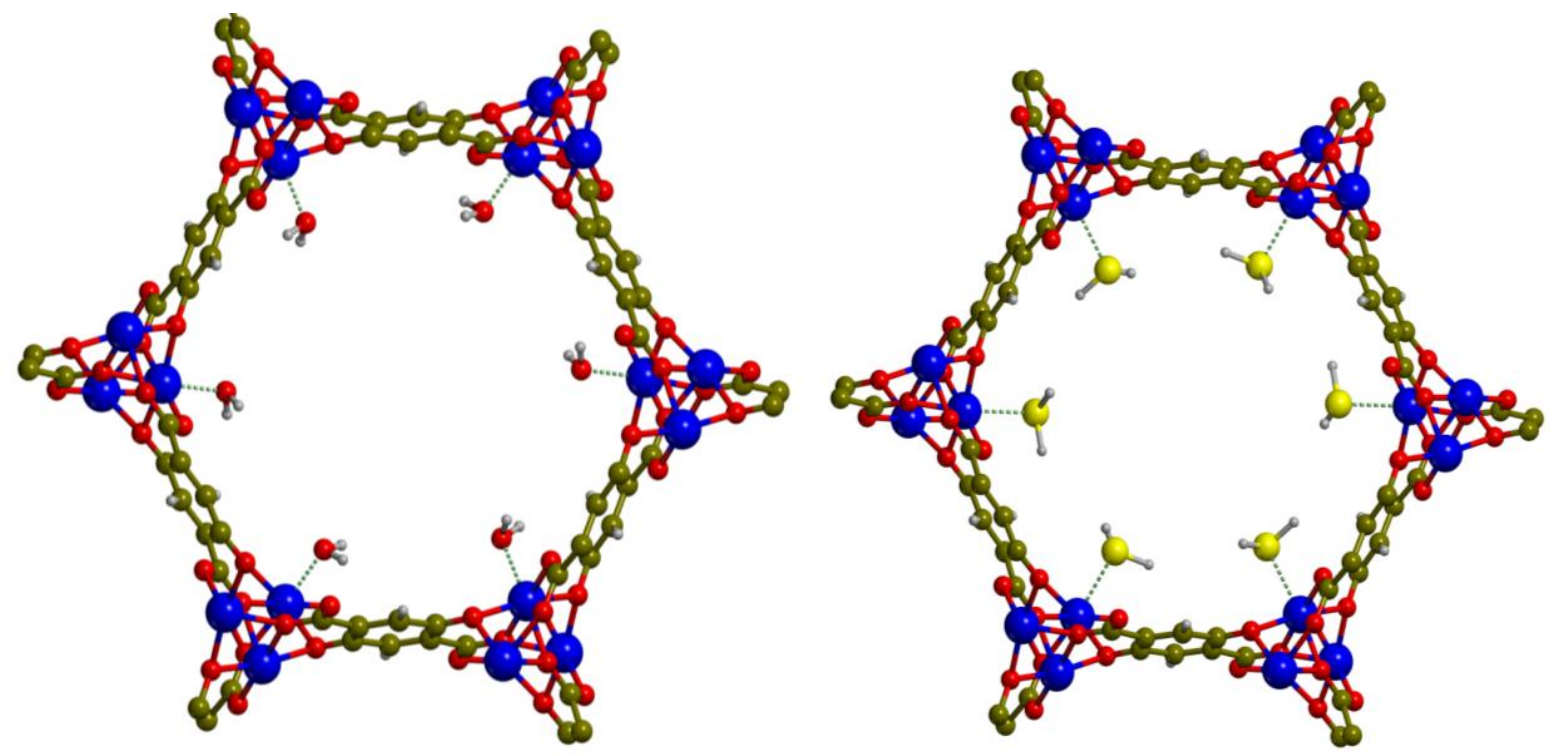

Figure 5: $\mathrm{H}_{2} \mathrm{O}$ (left) and $\mathrm{H}_{2} \mathrm{~S}$ (right) molecules as arranged in the CPO-27-Ni channels. Metal, sulfur, oxygen, carbon, and hydrogen atoms are blue, yellow, red, gray, and white, respectively.

As shown in Figure 5, computed results confirm that the principal interaction is observed between the $\mathrm{Ni}$ atom and oxygen and sulfur, even if the molecules are tilted toward a nearby oxygen atom of the framework thus indicating a weaker secondary interaction. This resembles what it was observed for the adsorption of $\mathrm{CO}_{2}$ in $\mathrm{CPO}-27-\mathrm{Mg}$ which was explained due to the presence of a negative potential around the oxygen belonging to the carboxylate group of the organic ligand. ${ }^{44}$

The computed Ni---S bond distance of $2.633 \AA$ is close to the experimental value as reported by Allan et al. ${ }^{23}$ (2.590 (1) $\AA$ ), and similar to bond lengths observed in $\mathrm{H}_{2} \mathrm{~S}$ loaded into Ni-zeolites. ${ }^{45}$. For $\mathrm{H}_{2} \mathrm{O}$, a good agreement is observed with respect to the $\mathrm{Ni---O}$ bond length (i.e., $2.10 \pm 0.04 \AA$ ) from the EXAFS spectrum. ${ }^{32}$ The computed enthalpies of adsorption of $\mathrm{H}_{2} \mathrm{O}$ and $\mathrm{H}_{2} \mathrm{~S}$ are underestimated with respect to microcalorimetry results. Indeed, experimentally determined $-\Delta \mathrm{H}_{0}(298 \mathrm{~K})$ is more than $100 \mathrm{~kJ} / \mathrm{mol}$ per $\mathrm{Ni}$ atom for water and $57 \mathrm{~kJ} / \mathrm{mol}$ per Ni atom for hydrogen sulfide. This underestimation can be ascribed to a general drawback of the DFT methods in describing the interaction of adsorbate with the $\mathrm{Ni}$ atom. However, computed data can be considered in semi-quantitative agreement with experiment.

\subsection{Structure stability of CPO-27-Ni upon adsorption of $\mathrm{H}_{2} \mathrm{~S}$}

In situ powder X-ray diffraction patterns were measured to check the structure stability of CPO-27-Ni in contact with $\mathrm{H}_{2} \mathrm{~S}$ for increasing times. The results are reported in Figure 6. A 
very small decrease in intensity of first diffraction peak is observed at the very initial exposure of $\mathrm{H}_{2} \mathrm{~S}$, as it is evident by comparing bold black curve and successive black curves; after this first evolution, no further changes were observed until $72 \mathrm{~h}$ (red pattern). Finally, the pattern obtained after 2 months shows a further small decrease in intensity. This does not affirm any loss of crystallinity, as the first diffraction peaks are sensitive to pore filling and packing of the sample inside the capillary. Moreover, no additional peaks are observed and those at higher angle well match in intensity with those recorded for pristine the CPO-27-Ni sample. This results show the high stability of CPO-27-Ni with respect to $\mathrm{H}_{2} \mathrm{~S}$ exposure.

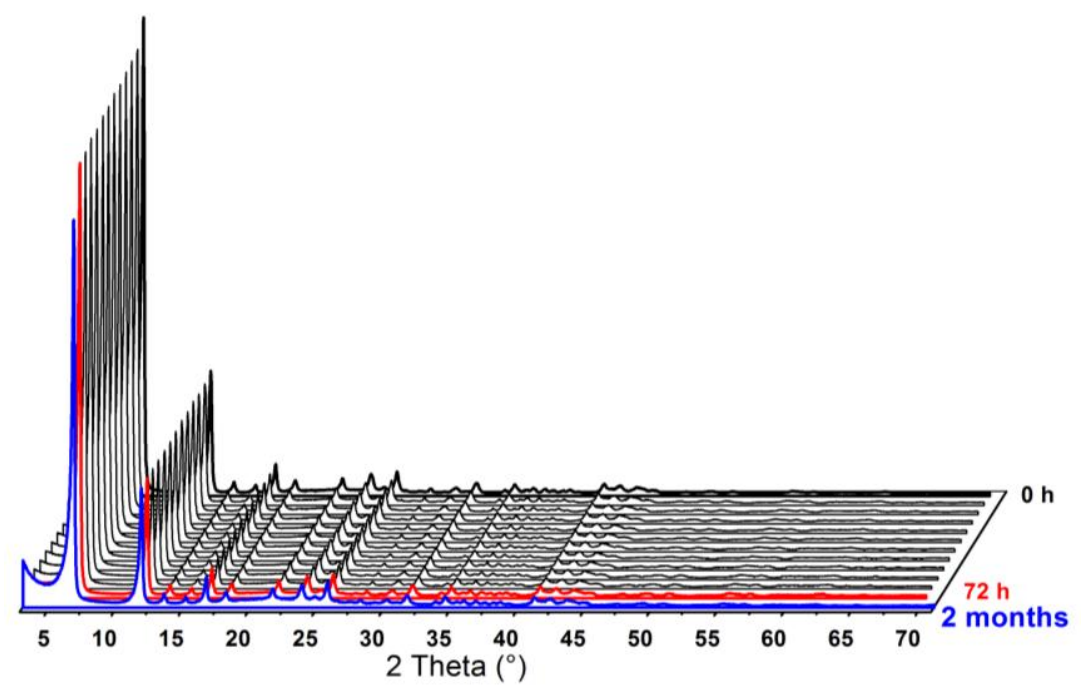

Figure 6: in situ powder X-ray diffraction patterns of CPO-27-Ni in contact with $\mathrm{H}_{2} \mathrm{~S}(60$ mbar) monitored as a function of time.

\section{Conclusions}

Combined use of spectroscopic with microcalorimetric data and computational evidences were able to characterize the properties of adsorbed $\mathrm{H}_{2} \mathrm{~S}$ on $\mathrm{Ni}$ sites of CPO-27-Ni. $\mathrm{H}_{2} \mathrm{~S}$ forms stable adducts at $\mathrm{Ni}$ sites, giving rise to species which are totally reversible only upon outgassing at $473 \mathrm{~K}$. Macroscopic change in colour of the sample that turns from yellow to dark green, indicates that $\mathrm{H}_{2} \mathrm{~S}$ has a much more strong effect on the electronic structure of $\mathrm{Ni}$ sites than $\mathrm{H}_{2} \mathrm{O}$. Heat of adsorption $\left(q_{\text {diff }}\right)$, obtained for $\mathrm{H}_{2} \mathrm{~S}$ adsorption isotherms on an activated sample is maintained in case of a reactivated CPO-27-Ni. The measured value of 56$58 \mathrm{~kJ} \mathrm{~mole}^{-1}$ (almost constant up to the loading of $\sim 0.7$ mole of $\mathrm{H}_{2} \mathrm{~S}$ per mole of CPO-27-Ni) indicates the formation of a medium-strong physisorptive interaction. Compared to other MOFs investigated so far for $\mathrm{H}_{2} \mathrm{~S}$ adsorption, CPO-27-Ni shows the highest uptake and high enthalpy of adsorption while maintaining its original structure and porosity. These key aspects 
make CPO-27-Ni a promising material for application in biogas or natural gas stream purification.

\section{Acknowledgements}

Giovanni Agostini and Richard Blom are acknowledged for fruitful discussion. We are grateful to E. Gallo and P. Glatzel (ESRF) for providing us the position of the high frequency d-d band obtained by RIXS prior publication. This work is supported by EU Seventh Framework Program (FP7), nanoMOF (CP-IP 228604-2)

\section{References}

1. Cheetham, A. K.; Ferey, G.; Loiseau, T., Angew. Chem.-Int. Edit. 1999, 38, 3268-3292.

2. Furukawa, H.; Ko, N.; Go, Y. B.; Aratani, N.; Choi, S. B.; Choi, E.; Yazaydin, A. O.; Snurr, R. Q.; O'Keeffe, M.; Kim, J., et al., Science 2010, 329, 424-428.

3. James, S. L., Chem. Soc. Rev. 2003, 32, 276-288.

4. Allendorf, M. D.; Bauer, C. A.; Bhakta, R. K.; Houk, R. J. T., Chem. Soc. Rev. 2009, 38, $1330-1352$.

5. Chavan, S. Characterization of Metal-organic Frameworks for Gas Storage and Catalysis applications. PhD thesis in Materials Science, University of Turin (I), Turin, 2010.

6. $\quad$ Corma, A.; Garcia, H.; Llabres i Xamena, F. X., Chem. Rev. 2010, 110, 4606-4655.

7. $\quad$ Czaja, A.; Trukhan, T.; Müller, U., Chem. Soc. Rev. 2009, 38, 1284-1293.

8. Horcajada, P.; Chalati, T.; Serre, C.; Gillet, B.; Sebrie, C.; Baati, T.; Eubank, J. F.; Heurtaux, D.; Clayette, P.; Kreuz, C., et al., Nat. Mater. 2010, 9, 172-178.

9. $\quad$ Li, J.-R.; Sculley, J.; Zhou, H.-C., Chem. Rev. 2012, 112, 869-932.

10. Sumida, K.; Rogow, D. L.; Mason, J. A.; McDonald, T. M.; Bloch, E. D.; Herm, Z. R.; Bae, T.-H.; Long, J. R., Chem. Rev. 2012, 112, 724-781.

11. Chavan, S. M.; Shearer, G. C.; Bloch, E.; Bordiga, S., ChemPhysChem 2012, 13, 445-448.

12. Kandiah, M.; Nilsen, M. H.; Usseglio, S.; Jakobsen, S.; Olsbye, U.; Tilset, M.; Larabi, C.; Quadrelli, E. A.; Bonino, F.; Lillerud, K. P., Chem. Mater. 2010, 22, 6632-6640.

13. Tanabe, K. K.; Cohen, S. M., Chem. Soc. Rev. 2011, 40, 498-519.

14. Borfecchia, E.; Maurelli, S.; Gianolio, D.; Groppo, E.; Chiesa, M.; Bonino, F.; Lamberti, C., J. Phys. Chem. C 2012, 116, 19839-19850.

15. Bloch, E. D.; Murray, L. J.; Queen, W. L.; Chavan, S.; Maximoff, S. N.; Bigi, J. P.; Krishna, R.; Peterson, V. K.; Grandjean, F.; Long, G. J., et al., J. Am. Chem. Soc. 2011, 133, 14814-14822.

16. Petit, C.; Bandosz, T. J., Dalton Trans. 2012, 41, 4027-4035.

17. Petit, C.; Mendoza, B.; Bandosz, T. J., ChemPhysChem 2010, 11, 3678-3684.

18. Watanabe, T.; Sholl, D. S., J. Chem. Phys. 2010, 133.

19. Hamon, L.; Leclerc, H.; Ghoufi, A.; Oliviero, L.; Travert, A.; Lavalley, J.-C.; Devic, T.; Serre, C.; Ferey, G.; De Weireld, G., et al., J. Phys. Chem. C 2011, 115, 2047-2056.

20. Hamon, L.; Serre, C.; Devic, T.; Loiseau, T.; Millange, F.; Ferey, G.; De Weireld, G., J. Am. Chem. Soc. 2009, 131, 8775-8777.

21. Heymans, N.; Vaesen, S.; De Weireld, G., Micropor. Mesopor. Mat. 2012, 154, 93-99.

22. Yang, Q. Y.; Vaesen, S.; Vishnuvarthan, M.; Ragon, F.; Serre, C.; Vimont, A.; Daturi, M.; De Weireld, G.; Maurin, G., J. Mater. Chem. 2012, 22, 10210-10220.

23. Allan, P. K.; Wheatley, P. S.; Aldous, D.; Mohideen, M. I.; Tang, C.; Hriljac, J. A.; Megson, I. L.; Chapman, K. W.; De Weireld, G.; Vaesen, S., et al., Dalton Trans. 2012, 41, 4060-4066.

24. Dietzel, P. D. C.; Panella, B.; Hirscher, M.; Blom, R.; Fjellvag, H., Chem. Commun. 2006, 959-961.

25. Becke, A. D., J. Chem. Phys. 1993, 98, 5648-5652. 
26. Lee, C.; Yang, W.; Parr, R. G., Phys. Rev. B 1988, 37, 785-789.

27. Miehlich, B.; Savin, A.; Stoll, H.; Preuss, H., Chem. Phys. Lett. 1989, 157, 200-206.

28. Grimme, S., J. Comput. Chem. 2006, 27, 1787-1799.

29. Civalleri, B.; Zicovich-Wilson, C. M.; Valenzano, L.; Ugliengo, P., CrystEngComm 2008, 10, 1693-1693.

30. Dovesi, R.; Orlando, R.; Civalleri, B.; Roetti, C.; Saunders, V. R.; Zicovich-Wilson, C. M., Z. Kristallog. 2005, 220, 571-573.

31. Dovesi, R.; Saunders, V. R.; Roetti, R.; Orlando, R.; Zicovich-Wilson, C. M.; Pascale, F.; Civalleri, B.; Doll, K.; Harrison, N. M.; Bush, I. J., et al. CRYSTAL09, University of Torino: Torino, 2009.

32. Bonino, F.; Chavan, S.; Vitillo, J. G.; Groppo, E.; Agostini, G.; Lamberti, C.; Dietzel, P. D. C.; Prestipino, C.; Bordiga, S., Chem. Mater. 2008, 20, 4957-4968.

33. Chavan, S.; Bonino, F.; Vitillo, J. G.; Groppo, E.; Lamberti, C.; Dietzel, P. D. C.; Zecchina, A.; Bordiga, S., Phys. Chem. Chem. Phys. 2009, 11, 9811-9822.

34. Chavan, S.; Vitillo, J. G.; Groppo, E.; Bonino, F.; Lamberti, C.; Dietzel, P. D. C.; Bordiga, S., J. Phys. Chem. C 2009, 113, 3292-3299.

35. Herzberg, G., Molecular Spectra and Molecular Structure II. Infrared and Raman spectra of polyatomic molecules. 7th ed.; D. Van Mostrand company, Inc. : Princestone, 1956.

36. Camposvallette, M. M.; Figueroa, K. A.; Latorre, R.; Manriquez, V.; Costamagna, J.; Otero, M., Vib. Spectros. 1992, 4, 77-90.

37. Wysokinski, R.; Morzyk-Ociepa, B.; Glowiak, T.; Michalska, D., J. Mol. Struct. 2002, 606, 241-251.

38. Gallo, E.; Lamberti, C.; Glatzel, P., Inorg. Chem. 2013, 52, 5633-5635.

39. Bordiga, S.; Groppo, E.; Agostini, G.; van, B. J. A.; Lamberti, C., Chem. Rev. 2013, 113, 1736-1850.

40. Glatzel, P.; Bergmann, U., Coord. Chem. Rev. 2005, 249, 65-95.

41. Singh, J.; Lamberti, C.; van, B. J. A., Chem. Soc. Rev. 2010, 39, 4754-4766.

42. Mino, L.; Colombo, V.; Vitillo, J. G.; Lamberti, C.; Bordiga, S.; Gallo, E.; Glatzel, P.; Maspero, A.; Galli, S., Dalton Trans. 2012, 41, 4012-4019.

43. Ciampoli.M, Inorg. Chem. 1966, 5, 35-40.

44. Valenzano, L.; Civalleri, B.; Chavan, S.; Palomino, G. T.; Arean, C. O.; Bordiga, S., J. Phys. Chem. C 2010, 114, 11185-11191.

45. Mariscal, R.; Navarro, R. M.; Pawelec, B.; Fierro, J. L. G., Micropor. Mesopor. Mat. 2000, 34, 181-194. 